Canadian University Music Review

Revue de musique des universités canadiennes

\title{
The Founding of CAUSM: A Personal Recollection
}

\section{Helmut Blume}

Volume 11, numéro 2, 1991

URI : https://id.erudit.org/iderudit/1014104ar

DOI : https://doi.org/10.7202/1014104ar

Aller au sommaire du numéro

Éditeur(s)

Canadian University Music Society / Société de musique des universités

canadiennes

ISSN

0710-0353 (imprimé)

2291-2436 (numérique)

Découvrir la revue

Citer ce document

Blume, H. (1991). The Founding of CAUSM: A Personal Recollection. Canadian University Music Review / Revue de musique des universités canadiennes, 11(2), 1-6. https://doi.org/10.7202/1014104ar

(c) Canadian University Music Society / Société de musique des universités canadiennes, 1991
Ce document est protégé par la loi sur le droit d'auteur. L’utilisation des services d'Érudit (y compris la reproduction) est assujettie à sa politique d'utilisation que vous pouvez consulter en ligne.

https://apropos.erudit.org/fr/usagers/politique-dutilisation/ 


\title{
THE FOUNDING OF CAUSM: A PERSONAL RECOLLECTION*
}

\author{
Helmut Blume
}

Dear friends:

I have been asked by our [CUMS] President, Dr. Philip Adamson, to talk about the beginnings of our Society, or rather of our parent organization CAUSM, the Canadian Association of University Schools of Music. He has given me about fifteen minutes for a crash course in this chapter of Canadian music history, so here goes.

The story begins with the Canada Council and Stanley House. To avoid any misunderstanding, let me just say that Stanley House is not the place where the Holy Grail of Canadian hockey, the Stanley Cup, is being kept. Still, the name "Stanley" does represent a tenuous link between hockey and the arts. It was Lord Stanley, the sixth Governor-General of Canada, who donated the famous hockey cup in 1893. Stanley House was the summer retreat he had built for himself a few years earlier at New Richmond, on the Gaspé Peninsula of Québec. It was also the place where the plans for the creation of CAUSM hatched in 1963 and '64.

Having been donated by its French-Canadian owner to the Canada Council in 1961, this beautiful property overlooking the Baie des Chaleurs opposite the coast of New Brunswick, became a unique contribution to the cultural life of Canada. To quote from the publicity given out at the time, the Council had decided "... to make of Stanley House a select meeting place for artists and scholars, away from the noise and distractions of the city, to think and exchange ideas with others in their fields, or with representatives of other disciplines, in a setting conducive to talk and discussion. The Council wished to encourage as free an expression of views and ideas as possible and to reduce formalities to a minimum. Programmes were to be kept flexible, and participants should have

* Editor's note: The following address was given by Helmut Blume at a dinner hosted by the Canadian University Music Society at the Learned Societies Conference. Queen's University, Kingston, 1991. Tribute was rendered there to Violet Archer and Professor Blume, who has graciously given permission to the Review to publish his address, with some minor editorial changes. 
leisure time between working sessions and discussions, to establish and strengthen lasting bonds of friendship and collaboration."

It was the late Peter Dwyer, then the Council's Assistant Director for the Arts, who organized the first summer meeting of musicians at Stanley House in 1963. I was one of those lucky enough to be invited by the Council to that first music conference. There were only a few of us, less than a dozen. After all, the house wasn't big enough to accommodate a crowd. Those present, according to a couple of photographs I kept, included: Lou Applebaum, at that time Music Consultant to CBC TV; Eugene Hallman, who was then CBC Programme Director; the late Roy Royal, Music Director of the CBC's International Service; the late John Adaskin (brother of Harry and Murray), who was at that time executive Secretary of the Canadian Music Centre; Roland Leduc, directeurgénéral du Conservatoire de Musique et d'Art dramatique de Québec; composers John Weinzweig, Gabriel Charpentier and François Morel, as well as a bright young man whom I tentatively identified on the photo as Kenneth Winters, then art and music critic of the Winnipeg Free Press. There may have been a few more, but if so, they were enjoying leisure time - or enjoying a swim - while the photos were taken.

We did have an informal agenda (topics to be discussed) under six main headings: Broadcasting, Music Education, Recording and Publication, the other Performing Arts (Opera, Theatre, Ballet), Subsidies and Community Support, and Miscellaneous (meaning, as always, everything else that bears on the above). In looking over the concerns of our little group of almost thirty years ago, I am impressed how topical they still are. This is not to say that nothing was done about them. On the contrary. Indeed, something is being done about them all the time. For the problems we confronted then continue to arise anew in a growing society, and each generation faces the challenge of dealing with them according to changing circumstances and new insights. To illustrate the point let me quote some of the topics we discussed in 1963:

- The need to relate new musical output more closely to its practical use in society.

- The urgent need for a study of the social and technological changes that are affecting the role of music in our culture.

- The need to establish Canadian contemporary creations as valid material for instruction and performance.

- The ability of our society to absorb the graduate musician.

- The need for a study to provide a guide and assistance to the $\mathrm{CBC}$ in the formation of policy with regard to music. 
"Plus ça change, plus c'est la même chose."

Still, one of the recommendations of that first meeting at Stanley House was acted upon immediately: namely, "To pursue the formation of a Canadian Association of Schools of Music." This project was close to my heart and I had proposed it at the meeting. I suppose that was the reason why I was subsequently invited by the Canada Council to convene and chair the second music meeting at Stanley House one year later, in July 1964: a meeting which was devoted entirely to discussing the pros and cons of establishing an Association of Canadian Music Schools.

Soon after the 1963 meeting I had composed a letter describing this project in some detail and had sent copies of it to Music Faculty and Department heads from coast to coast, wherever I could find them in the almanac of Canadian universities. The total came to eighteen, just about half the number of the current members of our Society. As you can see, we have made remarkable progress in numbers, for sure, but I dare say in raising consciousness, standards and quality as well.

The answers I received at the time were all quite positive, including some warmly encouraging words from Sir Ernest MacMillan to whom I had sent a courtesy copy. Boyd Neel, Dean of Music in Toronto at the time, was also supportive but felt that he couldn't add anything to what Arnold Walter and Ettore Mazzoleni had already told me. They had informed me that a similar project during the nineteen-fifties had come to nothing. But despite this ominous precedent they hoped it would succeed this time. Istvan Anhalt and Howard Brown had studied the history of the National Association of Music Schools in the United States and were optimistic that Canada could do as well. Jean Papineau-Couture reminded me that I had been wrong to include in my list the Ecole de Musique Vincent d'Indy of Montréal, as that school was only an affiliate of the Faculté de Musique de l'Université de Montréal and therefore not eligible to participate as an independent. Murray Schafer thanked me for calling him "Head of the Music Dept. at Memorial University" in Newfoundland: he was artist-in-residence there at the time, but wished to be kept informed until there would actually be a Music Department at that University.

Eventually, the Canada Council finalized the list of participants and sent out official invitations to the second music meeting at Stanley House in July 1964. Inevitably, there were last-minute cancellations. Boyd Neel was on his way to New Zealand to conduct concerts; John Weinzweig had been invited to come to Israel; Clément Morin was probably in France or Italy; the Albertans were perhaps in Banff; Roland Leduc was ill; and Lucien Brochu was also empêché 
d'assister à la conférence. Still, we did have a quorum, consisting of:

Murray Adaskin ( University of Saskatchewan)

Istvan Anhalt (McGill University)

Howard Brown (Mount Allison University)

Ronald Gibson (University of Manitoba)

Welton Marquis (University of British Columbia)

Arnold Walter (University of Toronto)

myself (McGill University)

as well as two observers:

François Bernier, directeur des études, Conservatoire de Québec, and

Keith MacMillan, Executive Secretary of the Canadian Music Centre, after the sudden death of John Adaskin.

So there you have your Fathers of Confederation! To the best of my knowledge there were no photographers present to take a picture of the group, so don't look for us in the Confederation Centre of the Arts in P.E.I.'s Charlottetown!

We were really quite modest in formulating our basic aims and purposes. When I look at the erudite subjects of some of the presentations at today's conference, such as "Dissonance Treatment in the English 'Conductus' Repertory," or "Post-positivistic Educational Thought: Implications of Empirical Research in the Realm of School Music," or: "Vers une nouvelle Modalité: Transformations modales dans la musique de Denys Bouliane," then all I can say is: "We weren't there yet in 1964!"

To show you where we were, let me quote the key section of our conference report to the Canada Council:

"... The aims and objectives in the formation of a Canadian Association of Schools of Music may be outlined as follows:

1 to provide a meeting-ground for heads and staff of music departments of Canadian universities and other professional schools of music for the exchange of views, the discussion of common problems and for mutual assistance;

2 to set minimum standards for music programmes at Canadian universities and other institutions providing professional music training;

3 to strengthen and maintain the position of music study in Canadian universities;

4 to serve as a consultative and advisory body for all Canadian university music departments and other professional music schools without in any 
way restricting individual initiative and freedom in teaching or administration;

5 to enlist the cooperation of member departments in matters relating to common concert and lecture projects;

6 to initiate projects and actions which, in the opinion of members, would be beneficial to the cause of music in Canada;

7 to stimulate and improve instructional methods at Canadian university music departments ... by symposia and publications."

There you have it: our "manifesto" of 1964. Much of it, and certainly its spirit, found its way into our constitution and is therefore familiar to you. Today, 27 years later, you are best qualified to judge whether our "Credo" of then has stood the test of time. However, the most important practical aspect of our resolution was contained in one short sentence toward the end of our Report, namely this:

The conference agreed to form a small committee for the purpose of working out a tentative constitution and by-laws under which such an association might operate effectively.

We were incredibly lucky that we had in our midst the all-round genius Dr. Arnold Walter. He had obtained his doctorate in Law, at the University of Prague, at the age of 24 . Only then did he turn to the serious study of musicology, composition and piano in Berlin, where he also became a feared music critic at a social-democratic newspaper, a fervent anti-Nazi, and a political refugee who escaped the Gestapo-grabbers by the skin of his teeth. "You are a lawyer", I pleaded with him at Stanley House, "who else could write our constitution and the by-laws? Please!" He did. And in a remarkably short time. Laster that year the "small committee" referred to in our Stanley House Report and consisting of Arnold Walter as chairman, Clément Morin, of l'Université de Montréal, Lucien Brochu, of L'Ecole de Musique, Université Laval in Québec City, Istvan Anhalt and myself, met in my office at McGill for a weekend conference, grateful to receive Arnold Walter's professional submission of a constitution and bylaws. And early the following year, February 1965, the Canadian Association of University Schools of Music - with the unmusical acronym CAUSM - was duly constituted in Ottawa before a sizeable representation of Canada's university Music Faculties and Departments, with Arnold Walter as president and Clement Morin as vice-president, in an appropriate balance of our English and French constituencies.

Arnold Walter did more than establish the legal foundations of our Association. Scholar that he was, he promoted our application for admission to the Canadian 
Conference of Learned Societies. Naive as I was, I thought acceptance was a foregone conclusion. But it wasn't quite that simple. There were still those in the high councils of "Academe" who questioned the eligibility of musicians for membership in the esoteric world of scholars. But we overcame that hurdle, too.

During a quarter of a century this Learned Society of ours has proved its value and substance in the spirit of those who planned it at Stanley House under the sponsorship of the Canada Council. The constitutional revision of 1971, by Donald McKellar and Lorne Watson, to admit individual members in addition to the institutional membership, and the more recent name-change of the organisation, have broadened the function and have clarified the academic identify of the Society.

It has become a bond among the large number of Canada's university music schools, a meeting-place for colleagues, a prism of individual and collective achievement in the various disciplines of our vocation, and a safeguard of our rightful place in our universities. I am delighted! And I am grateful to have been given this opportunity to talk to you about the past.

The future is yours. 